\title{
CHILDREN EDUCATION IN THE ISLAMIC FAMILY A Study Of Tuhfah Al Maudud Bi Ahkam Al MauludBy Ibn Qayyim Al Jauziyyah (w. 751/1350)
}

\author{
Muhammad Idris
}

The College for Islamic Studies of Al-Hikmah, Medan - Indonesia email: muhammadisris@gmail.com

\author{
Abd. Mukti \\ State Islamic University of North Sumatra, Medan - Indonesia
}

\begin{abstract}
This study aimed to reveal how IbnQayyim al-Jawziyyah thought about the education of children in Islamic families as in his paper Tuhfah al Maudud bi Ahkam al Maulud. There are three problem formulations proposed in this study: first, how the intellectual social conditions of writing the book Tuhfah al Maudud bi Ahkam al Maulud; Second, how is the thinking about the education of children in the Islamic family contained in the book of Tuhfah al-Maudud bi Ahkam al-Maulud; Third, how relevant the idea is to contemporary Islamic education. This research is library research; And using a social history approach; The steps are taken: first, collecting reference works, grouped into two: primary and secondary sources (other sources in the same theme are used as a complement); Second, using content analysis methods, with the steps: first, reading the text and giving a brief note on the margin when it finds the required information; Second, categorize and identify each item according to a cognate theme; Third, comparing all categories, both major and minor; Fourth, after all data is categorized into categories large and small, review, to ensure that the information is categorized as appropriate; Fifth, re-examine the original text, and ensure that all the information that needs to be categorized has all been listed; Sixth, material analysis, interpretation, and meaning. Furthermore, Ibn al-Qayyim's ideas on child education are analyzed by taking into account the potential relevance for today's education. The findings of this study: first, where during Ibn al-Qayyim's lifetime, the political, social, and educational conditions were in an unstable state. Second: education for children in Ibn al-Qayyim's thinking as stated in his paper Tuhfah al-Maudud bi Ahkam al Maulud consists of: moral education for children; Aqidah education for children; And education of worship for children. Third: education for children according to Ibn al-Qayyim's thought is still relevant, evidenced by the similarity of discussion and practice of education in today's world.
\end{abstract}

Key Words: Children Education, Isalmic Family, Tuhfah al Maudud bi Ahkam al Maulud, IbnQayyim al Jauziyyah

\section{INTRODUCTION}

Child is a gift and a trust from Allah SWT, Where every human being who already married would crave it. But whether after the birth of the baby then the life of parents become happy?. The answer can be yes or not. It depends on the pattern of education and the environment that color it. 
Undeniable today with the rapid development of technology as a sign of globalization has made most parents anxious about the development of their children. They are afraid that their son will fall into a moral and mental decline. Therefore, if they wrongly determine the policy in providing education, the child's life will be far from the original expectations. He will be trapped in the pattern of consumerism, hedonism, moral damage, and weak personality. Surely it is not wanted by any parent who believes.

The data of the last ten years, reported by institutions that examine the lives of teenagers indicate a situation of concern (access to pornography, premarital sex, abortion, brawls, begal and other). This alarming situation, according to AbdMukti indicated a mistake in education, especially in the family. This is also an indication that proves the failure of the child protection system, many of the neglect by the State so that children continue to be victims and perpetrators.

Therefore Islam has offered a solution to this problem its teachings contained in the Qur'an and hadith have given enlightenment and considerable attention in the field of children's education. In Islam parents are required to pay attention to every phase of the development of the child since still in the womb, the birth, the rada ah (breastfeeding), the childhood, adolescence, to adulthood. ${ }^{1}$

This study was limited to a book of Tuhfah al Maudud bi Ahkam al Maulud written by IbnQayyim al Jauziyyah (d.751/1350). More specifically the problem of this research is formulated into three issues that are related to each other namely; What is the intellectual social condition of the book of Tuhfah al Maudud bi Ahkam al-Maulud. How the thinking about the education of children is in the Islamic family contained in the book Tuhfah al Maudud bi Ahkam al Maulud. How relevant is the thinking to contemporary Islamic education. This study aims to answer the problem formulation is to know; The intellectual social conditions of the book of Tuhfah alMaudud bi Ahkam al-Maulud. The idea of a child's education in an Islamic family is contained in the book of Tuhfah al-Maudud bi Ahkam al-Maulud, The relevance of such thoughts to Islamic education today.

1 Muhammad ibnAbi Bakr ibn Ayyub ibn Qayyim al Jauziyyah, Tuhfah al Maudud bi Ahkam al Maulud (Makkah: Dar `Alam al Fawaid, 1431/2010), p. 5-6. 


\section{METDHODOLOGY}

By focusing on the thinking of a scientist as stated in one of his work, this research is a library research. This research is conducted by using social history approach because the education of children is directly related to the interrelation between the parties involved in intellectual activity and also the wider society.

With this approach, this study used the following steps:

First, collect reference works or research data sources which are then grouped into two: 1) Primary source is Tuhfah al Maudud bi Ahkam al Maulud. In this study the edition of 'UsmanibnJum 'ahDumairiyah published by Dar' Alam al Fawaid (Makkah, 1431/2010) as the best available edition. 2) Secondary sources covering works on other children's education mainly play a role in assisting the understanding of Tuhfah al Maudud bi Ahkam al Maulud. In addition, historical books and biographical dictionaries provide historical social-intellectual backgrounds from times and places relevant to earlier studies and earlier studies. ${ }^{2}$

Second, do a thorough study of the work that became the object of research by using content analysis method (content analysis). This not only includes Ibn alQayyim's thought but also the social-intellectual background and scientific tradition that inspires his educational formulation. According to Philip Mayring at least there are several steps used in content analysis methods:

1. Read the text and give a brief note on the margin when it finds the required information.

2. Categorize and identify each item according to a cognate theme.

3. Compare all major or minor categories.

4. After all data is categorized into categories large and small, review to ensure that the information is categorized as appropriate.

5. Re-check the original text and ensure that all the information that needs to be categorized has all been listed.

6. Material analysis, interpretation, and meaning.

Furthermore, Ibn al-Qayyim's ideas about child education are analyzed by taking into account the potential relevance for today's education.

${ }^{2}$ Syahrin Harahap, Metodologi Studi Tokoh Pemikiran Islam (Jakarta: Prenada Media Group, 1432/2011), p. 4. 


\section{FINDINGS AND DISCUSSION}

\section{The Thought of IbnQayyim al-Jauziyyah about Children Education in The Isalmic}

\section{Family}

The primary source book in this study consists of 17 chapters, then analyzed in this dissertation into three main themes. The three main themes in question are firstly, moral education for children (discussed at this point). Secondly The Aqidah education for children. Thirdly, the education of worship for children.

\section{Moral Education for Children}

The sub-points in this first theme are; Love and compassion for the child because Allah swt. Pray for the good of the child, giving a good name for children, wise in responding to the needs of children. Keep children away from negative things. Give a kiss to the child. It is permissible to bring children in prayer even though the sanctity of their clothing is questionable. Appreciate the interests and talents of children. And be fair to all children.

\section{Love to Children Because of Allah SWT.}

Ibn al-Qayyim said that if the presence of a child on the basis of love and affection for Allah Almighty, it will create a good impression for the development of children in all aspects. That is the first and foremost capital for the child, to receive the next educational materials. Thus, the child is an investment of the world and the hereafter, if he lives full of love and compassion from both parents because Allah swt. Similarly, the born child, God willing, will someday worship Allah Almighty. And not associate Him with anything. ${ }^{3}$

\section{Pray for the Happiness of Children}

Ibn al-Qayyim said, one form of moral education for children is to pray for the good of the child. He leaned on the contents of the prayer taught by al-Hasan (w: 110/728), namely: May you be blessed to the child given and thank the Lord who gave it, May the child grow fast and you get the devotion from him) ".4

${ }^{3}$ Ibn Qayyim Al-Jauziyyah, Tuhfatul-Maudud, p. 10.

${ }^{4}$ IbnQayyim Al-Jauziyyah, TuhfatulMaudud, p. 34; Diriwayatkan At-TabranidalamAdDu'a', no. 945, juz 2, p. 1243-1244, isnad-nyahasan, mauquf kepada Al-Hasan Al-Basri; Muhammad ibnAbiBakribnAyyubibnQayyim Al-Jauziyyah, Ad-Da' wad-Dawa' (Makkah: Dar 'Alam Al-Fawaid, 1429), p. 13 
As much as any parent's efforts in caring, educating, educating and directing the child, if Allah swt. Would not deign to make him a righteous son, surely he would never be a pious son. This shows how great the power of Allah SWT, and how small the power of parents. This is clearly motivating to further build dependence and a sense of awareness to Him.

\section{Giving the Good Name for Children}

The name is something that really needs attention, because the Prophet. So paying attention to naming something, anything, everything should be avoided from bad naming, the Prophet Replace bad names with good names. ${ }^{5}$

\section{Wise in Response to the Need of Children}

Before feeding the child to another woman, at least the child must breastfeed to her biological mother for two or three days. This custom never applies to the Prophet, where he was raised by Bani Sa'ad. According to medical science, breast milk in the first 24 hours contains a yellowish colostrum, rich in secretory immunoglobulin A (sig A) that serves the gastrointestinal tract so that germs can not enter the bloodstream and will protect the baby until the immune system (immune system ) works fine.

Ibn al-Qayyim said, both parents need not be confused when children cry and scream, because it has certain benefits for children. Let the child cry for a moment also teaches the baby to be calm and patient, if immediately ignored then the child will be depressed and feel constrained, similarly, certain changes in the growth of teeth. As teething grows, it should be rubbed on the teeth where it grows, butter or cheese. 6

\section{Keep Away the Children from Negative Things}

Keeps children away from loud voices of scorn, terrible sights, irregular movements; If it is not avoided it will damage and weaken the power of reason the child.7 Even the words of Ibn al-Qayyim, during pregnancy, thoughts and negative

\footnotetext{
5Ibid.,p. 66, 68-69, 70-71.

6Ibn Qayyim Al-Jauziyyah, Tuhfatul Maudud, p. 340.

${ }^{7}$ Ibid.,p. 342.
} 
things that happen to a mother affect the fetus in its womb, such as seeing dirty pictures, pale colors, and the houses are spooky and narrow.

\section{Giving kissing for the Children}

The next moral education according to Ibn al-Qayyim, is to kiss intimately to the child. In addition, the form of intimacy that the child expected is in the form of love utterances, play together, present at child's precious time, and give gifts. The generation of salaf advocates, in order kissing the child fairly. ${ }^{8}$

\section{Respect for Children Interest and Talent}

The child is the soul that is present into this world, bringing with it a unique interest and talent to be realized. The innate ability of the child in the form of interests and talents, can develop well and perfectly, if parents are able to understand and direct it correctly, that is by teaching certain skills according to interests and talents of children, which can be utilized for the benefit of his life and the Muslims, such as riding, Industry and so on. ${ }^{9}$

Deservedly concerned with the condition of the child, one of them is to direct them to deeds in accordance with their talents and readiness to do so. Having known the talent, should not be transferred to the actions that are other than, as long as the talent is still in the corridor allowed by religious shari'a. Because, if they are directed to something that they themselves are not prepared to do, then they will not succeed to achieve it, and otherwise they will lose their talent.

\section{Fair to Al Children}

In giving something to the child, it should be evenly distributed or not at all. Because of unfair giving, it is an unjust act. ${ }^{10}$

${ }^{8}$ Ibid., p. 336.

9Ibn Qayyim Al-Jauziyyah, Tuhfatul-Maudud, p. 354; Ragib As-Sirjani, Al-'IlmuwaBinaulUmam, DirasahTa'siliyyah li Dauril-'Ilmi fi Binaid-Daulah(Kairo: MuassasahIqra', 1428/2007), p. 17. juz 5, p. 40.

10Ibn Qayyim Al-Jauziyyah, Tuhfatul Maudud, p. 334-337, 411; Bakkar, Masarul Usrah, 


\section{Faithfull Education for Children}

For children, The parents who leads him to his nature (faith) or turns into a crook (mushrik) with the permission of Allah. Every child is born with fitrah; Even so, it does not mean the child already knows how to mute God. The nature can emerge and develop, if gained guidance and education gradually, according to revelation and reason. ${ }^{11}$

As for the sub-points in this discussion is firstly, echoing the azan in the baby's right ear and iqamah in his left ear. Secondly, teach monotheistic sentence. Thirdly are heaven and hell. Here are the ways that Islam offers, in planting aqidahIslamiyah for the baby to stay straight.

\section{Teaching the TauhidWords to Children}

If the child has begun to speak well, drop the child's tongue with honey and warm water mixed with iodized salt to remove the moisture or mucus that troubles the child speaking; then the first and always taught is La IlahillallahMuhammadurRasulullah. With hope, hopefully when he is able to understand its meaning, then he will know that he is a servant of God, and Allah has power over him. ${ }^{12}$

\section{Introducing Allah to Children}

Allah SWT. Always called repeatedly in the Qur'an and hadith, as well as on the heart, verbal, and deeds of the believers. However, have educators (parents and adults) measured the extent of their children's recognition (ma`rifah) against God. Is it enough to know Him by knowing and memorizing His names and attributes. Knowing and memorizing is something important, but more important is how the next attitude. ${ }^{13}$

The correct introduction, as revealed by Ibn al-Qayyim in al-Fawaid, is an introduction that can cause feelings of shame, love, attachment, longing, repentance, closeness, and hope only to Him. When the baby, hurrying when he hears his call, it is certain that he knows God well. That is because by welcoming His call, he can

\footnotetext{
${ }^{11}$ Ibn Qayyim al-Jauziyyah, Tuhfatul-Maudud, p. 377.

${ }^{12}$ Ibn Qayyim al-Jauziyyah, Tuhfatul-Maudud, p. 339; Nurud-Din As-Salimi, Talqinus Sibyan(Oman: Al-Maktabah Al-Iliktruniyyah, 2004), p. 10.;'Abdul-Latif Asyur, Mustasyfa 'Asal AnNahl At-Tadawi bi `Asl An-Nahl(Maktabah Al-Quran, 1306/1985), p. 59.

${ }^{13}$ Ibn Qayyim al-Jauziyyah, Tuhfatul-Maudud, p. 184; Yusuf KhatirHasan As-Suri, Asalib Ar-Rasul fid-Da wahwat-Tarbiyyah(ttp.: Sunduq At-Takaful, t.t.), p. 38.
} 
dialogue with Him, denounce the problems encountered, then ask for His help until afterwards he gets His enlightenment by knowing and memorizing His names and attributes. Knowing and memorizing is something important, but more important is how the next attitude. ${ }^{14}$

\section{Introducing Prophets to Children}

To care for nature, to fight lust, and to fight demons, children need God's guidance and guidance. But the God of the Unseen can not be seen directly, even he himself is powerless to come face to face with Him. Therefore, Allah `AzzawaJalla sent his messengers in the form of angels and human choices to guide and guide children how to know the Creator and how to live this life well.

\section{Heaven and Hell}

At the age of 40 days from birth, then at this age he began to laugh; And this is the first time the baby has a process of thinking. At the age of 2 months, he begins to dream, then will develop his reason and gradually gradually to reach the age of tamyiz. And about the age of this tamyiz is not determined the age limit (there is a opinion of 3 years, 5 years, or 7 years). But IbnTaymiyya said that the Islamization of a 3-year-old child is legitimate, given that he has understood Islam well.

But it is clear that when the baby is 7 years old, it means He has been commanded to perform the prayers. If he is reluctant, when he is 10 years old, then limited to 5 hours old, only limited training and self-discipline to the obligation of prayer 5 time. The majority of jurists agree that it is valid for him at that age, but in the case of furu> 'has not been charged. ${ }^{15}$

Taklif in problem of furu ' has been charged to the child when they are already entered to adulthood. There is no age limit of children is called adult, there is a opinion since the age of 12 years, or 14 years or 15 years, and some even argue 18 years. Of these differences, all agree with one thing, namely the removal of semen for boys, and menstruation for girls. ${ }^{16}$

\footnotetext{
Fawaid, p. 45.

15 Ibid., p. 416.

16Ibid., p. 417-425.
}

14Ibn Qayyim al-Jauziyyah, Tuhfatul-Maudud,, p. 364; Ibn Qayyim Al-Jauziyyah, Badai`Al- 
After the age of 40 years, a person's condition begins to decline; its strength gradually begins to weaken, as the power arises earlier in stages. The power of a human being is between two weaknesses, and his life is between two deaths.

If the condition has been fragile, it means the death of death is closer to him than the close hand to mouth. As the hour of death approaches, and the ration of his life has been perfected, then came the messenger of Rabb who will move him from the mortal world into the eternal realm. The angel who was given the task of plucking up the spirit approached the man, calling his soul. If the spirit is good, then he will come out of his body in a state of praise and will get a pleasant life.

\section{Aqiqah for Children}

'Aqiqah is one effort to revive the Sunnah of the Messenger of Allah. Malik (d.179/795) calls it Sunnah obligatory: the Sunnah is mandatory where among the benefits is in the framework of worship performed to bring a child to God when first born into the world. Malik explains that rationalists deny this extinction, even though much of the information about this matter is valid. ${ }^{17}$

\section{Shave Hair and Charity worth the Scales}

It was prescribed to weigh baby's hair, then give charity to money, or silver, for the interest in the way of Allah or give it to ibnsabil. Shaving hair is one way to get rid of dirt from baby's head and to throw out weak hair to grow new hair stronger, better, and more comfortable for the head.

In addition, make the child's head feel light and open pores, so the temperature from the head can come out more easily and smoothly. Even this shaving, can strengthen the view, sense of smell, and hearing. ${ }^{18}$ Prophet Muhammad Also accustom to wet the head of the baby with a fragrant oil za faran fragrant and has a beautiful color, instead of the blood of animal sacrifices that smelled rancid and unclean. ${ }^{19}$

\footnotetext{
${ }^{17}$ Ibn Qayyim al Jauziyyah, Tuhfatul Maudud, p. 93, 100.

18Ibid.,p. 101.

${ }^{19}$ Ibid.
} 


\section{Circumsision for Children}

Messenger of Allah.Making circumcision a subject of all fitrah.Fitrah there are two types; First, the heart-related nature of knowing God, loving him, and preferring Him above others. Second, the nature associated with the deeds of action, which are all behaviors: cutting mustache, gargling, beristinsyaq, bersiwak, combing hair, nail clippings, shaving pubic hair, circumcision, pulling armpit hair'. ${ }^{20}$

Associated with the first nature that is by purifying the soul and cleaning the liver, while associated with the second nature is by cleaning the body. Each of the two types of nature is mutually supportive and reinforcing. The properties of nature entirely contain the meaning of holiness and cleanliness, removing the remains of the dirt normally left by the demons embedded in a human being, displaying good looks, beautify the physical, and to control the lust if it is excessive it will equate humans with animals; But if it is totally eliminated, it equates people with inanimate objects; Because that circumcision stabilizes the lust; Found many men and women who are not circumcised, not satisfied in having sexual intercourse. ${ }^{21}$

Satan is also hiding in pubic hair and long nails; And foreskin (skin circumcision) that is not cut, worse than pubic hair and nails that are not cut. Above all, it can not be denied that cutting off the skin is a sign of human servitude to Allah ‘AzzawaJalla.

\section{Puncture Ear for Girls}

Pierced ears, allowed for women because girls need jewelry for themselves so that ear piercing contains maslahah for him. As for piercing the ears for men, there is not the slightest benefit - this includes also cutting one of the limbs, not for the benefit of the world or the benefit of the Hereafter, therefore it is forbidden. ${ }^{22}$

Aisyahra. (W 57/678) once said that, the jewels in his ears are moving and turning in sahihain: when the Prophet (saas) Encourage women to give charity, they immediately throw their khars (a kind of earrings that hung on the ear). It is permissible to pierce ear lobe, because Allah and His Messenger know what women need and what their character tends to be for jewelry and all its knick-knacks.

\footnotetext{
20Ibid.,p. 233, 245.

21Ibid.,p. 274.

22Ibid., p. 308-309.
} 


\section{Obligation to Perform Sholat}

The obligation of parents is to educate the child to pray and do good, namely obey Allah and His Messenger. Implanting and guiding the good for the baby since he was little is a beautiful thing. With that, he will start a note on the white sheet of his life with closeness to Allah swt.23

When a child is seven years old, he is entering the age of tamyiz, and he is commanded to perform the prayers. IbnMiskawayh $(421 / 1030)$ says the baby has two characters. The first character is a gifted child type. This type does not require repeated instruction, because it has the character of love for good. But there is another type, the type of child who is less talented. ${ }^{24}$

When a child is ten years old, his physical will grow stronger, his mind develops and becomes more able to perform worship. Therefore, at this age, the child may be beaten if he is reluctant to establish prayer, neglect to the end of time as commanded by the Prophet. Beating here is a blow to training and self-habits, not to hurt and hurt. ${ }^{25}$

Prayer is the greatest helper; Produce the good of the world and the Hereafter; Eliminating the damage of the world and the afterlife; Wipe away sin; Treat the liver; And body. ${ }^{26 I b n}$ al-Qayyim said, prayer activities, especially night prayer can strengthen body immunity. According to him, all series and types of worship, beneficial to every Muslim. ${ }^{27}$

\section{CONCLUSION}

From the previous description it can be concluded that during the life of Ibn al-Qayyim, the political, social and educational conditions were in an unstable condition. The instability of these conditions comes from internal Muslims themselves, and rongrongan from external Muslims. The effects of all are including the weakening of the economic sector and education, especially in the family.

23 Muhammad ibn Humail Zainu, KaifaNurabbiAuladanawa ma HuwaWajibul-Aba'walAbna'(Makkah: Darul-Hadis, tt.), p. 37.

24 Ahmad ibn Muhammad Miskawaih, Tahzibul-Akhlaq(Beirut: Mansyurat Al-Jamal, 2011), p. 265.

${ }^{25}$ Ahmad Fu'ad Al-Ahwani, At-Tarbiyyahfil Islam (Mesir: Darul-Ma`arif, 1967), p. 141.

${ }^{26}$ Ibn Qayyim Al-Jauziyyah, At-Tibbun-Nabawi,p. 163.

27Ibn Qayyim Al-Jauziyyah, At-Tibbun-Nabawi,p. 193. 
The education for the children in Ibn al-Qayyim's thought as contained in his paper Tuhfah al Maudud bi Ahkam al Maulud consists of: 1) moral education: love and affection for the child for God; Pray for the good of the child; Giving a good name to the child; Wise in responding to the needs of the child; Keep children away from negative things; Give a kiss to the child; Bringing children in prayer even though the sanctity of their clothing is doubted; Respect the interests and talents of children; And be fair to all children. 2) Aqidah education: echoes the azan in the right ear and iqamah on the left ear; Teach monotheistic sentence; And heaven and hell. 3) Education of worship: men-tahnik children; Aqiqah child; Shaved head hair and charity worth his scales; circumcision; Pierced ears of girls; Not burdened with what comes out of the child's cub; Not burdened with fluid coming out of the child's mouth; And discipline children in worship.

The education of children according to Ibn al-Qayyim's thought is still relevant; evidenced by the similarity of discussion and practice of education in the world today, the stages in providing subject matter according to interests and talents of children rather than intervention and authoritarian parents. The giving of the subject matter according to his interests and talents was given after the child mastered the science of syar'i first. Practically means there should be a father discussion forum, and or mother discussion forum that discusses how good parenting patterns for children, from birth to adulthood According to the Qur'an and the Prophet's guidance. With the discussion forum is expected every parent and educator able to provide education or good parenting.

\section{REFERENCES}

Al-Ahwani, A. F. (1967). At-Tarbiyyahfil Islam.Mesir: Darul-Ma`arif

As-Salimi, N. (2004). Talqinus Sibyan. Oman: Al-Maktabah Al-Iliktruniyyah

As-Sirjani, R. (2007). Al-'Ilmuwa Binaul-Umam, Dirasah Ta'siliyyah li Dauril-'Ilmi fi Binaid-Daulah. Kairo: MuassasahIqra.

As-Suri, Y. K. H. (ttp).Asalib Ar-Rasul fid-Da`wahwat-Tarbiyyah: Sunduq At-Takaful.

Asyur, A. L. (1985). Mustasyfa 'Asal An-Nahl At-Tadawi bi `Asl An-Nahl. Maktabah AlQuran.

Harahap, S. (2011).Metodologi Studi Tokoh Pemikiran Islam. Jakarta: Prenada Media Group. 
Jauziyyah. A. J. (2010).Tuhfah al Maudud bi Ahkam al Maulud.Makkah: Dar `Alam al Fawaid

Miskawaih, A. M. (2011). Tahzibul-Akhlaq.Beirut: Mansyurat Al-Jamal.

Zainu, M. H. (ttp). Kaifa Nurabbi Auladanawa ma Huwa Wajibul-Aba'wal-Abna'. Makkah: Darul-Hadis. 